\title{
Ryszard Kapuściński w Hiszpanii i Ameryce Łacińskiej
}

\section{Ryszard Kapuściński in Spain and in Latin America}

Abstract: The article consists of three parts. First two parts have a historic-literary character as they discuss the following: how the writings of Kapuściński reached Spain and Latin America; how they were received there; when and due to which factors the reporter achieved success and his books started to gain popularity. The third part is a theoretical attempt at conceptualising the issue. Using the enquiries in libraries as well as archives, the conducted interviews and the reception theory of Hans Robert Jauss as well as the concept of the "horizon of expectations", the author tries to explain why the writings of Kapuściński made a name for themselves in these particular regions of the world.

Keywords: Ryszard Kapuściński, Ryszard Kapuściński in Spain, Ryszard Kapuściński in Latin America, Polish reportage, reception theory

Streszczenie: Artykuł składa się z trzech części. Dwie pierwsze mają charakter historycznoliteracki, mowa w nich o tym, jak twórczość Kapuścińskiego dotarła do Hiszpanii i do Ameryki Łacińskiej, jak była tam odbierana, kiedy i za sprawą jakich czynników reporterowi udało się odnieść sukces, a jego książki zaczęły cieszyć się popularnością. Trzecia część jest natomiast próbą teoretycznego ujęcia zagadnienia. Na podstawie kwerend bibliotecznych i archiwalnych, przeprowadzonych wywiadów oraz korzystając z teorii recepcji Hansa Roberta Jaussa i konceptu „horyzontu oczekiwań”, autorka stara się wyjaśnić, dlaczego dzieła Kapuścińskiego zaistniały właśnie pod tymi szerokościami geograficznymi.

Słowa kluczowe: Ryszard Kapuściński, Ryszard Kapuściński w Hiszpanii, Ryszard Kapuściński w Ameryce Łacińskiej, polski reportaż, teoria recepcji

\section{Przekroczyć granicę. Wstęp}

Jednym z najbardziej charakterystycznych lejtmotywów twórczości Ryszarda Kapuścińskiego jest granica. Granica, którą chciał przekroczyć od najmłodszych lat, czy to wpatrując się w sunące po Pinie statki, wypływające z poleskiego Pińska 
i „opływające cały świat” ${ }^{1}$, czy też obserwując na stacji pociągi odjeżdżające w nieznanym mu kierunku.

Zastanawiałem się, co się przė̇ywa, przechodząc granicę. Co się czuje? Co myśli? Musi to być moment wielkiej emocji, poruszenia, napięcia. Po tamtej stronie - jak jest? Na pewno - inaczej. Ale co to znaczy to - inaczej? Jaki ma wygląd? Do czego jest podobne? A może jest niepodobne do niczego, co znam, a tym samym niepojęte, niewyobrażalne? Ale, w gruncie rzeczy, największe moje pragnienie, które nie dawało mi spokoju, nęciło mnie i dręczyło, było nawet skromne, bo mianowicie chodziło mi o jedno tylko - o sam moment, sam akt, najprostszą czynność przekroczenia granicy².

Przekroczyć granicę, marzenie małego chłopca, o którym wspomina na pierwszych stronach Imperium, marzenie studenta, zrealizowane wreszcie w 1956 roku, kiedy pojechał na kongres Światowej Federacji Młodzieży Demokratycznej do Kijowa, wreszcie marzenie początkującego reportera, przywołane na stronach Podróży $z$ Herodotem, kiedy w tym samym 1956 roku przez Rzym wyrusza w swoją pierwszą daleką podróż na pokładzie czterosilnikowego kolosa Air India International.

Tysiące podróży, setki tysięcy kilometrów, niezliczone granice. Nie tylko te widoczne na mapie świata, ale także granice w czasie oraz te, dzielące różne gatunki literackie. A ile granic przekroczyła jego twórczość? Niektóre książki zostały przetłumaczone na ponad trzydzieści języków, jak choćby Cesarz, który doczekał się trzydziestu siedmiu przekładów.

W Polsce jednak, mimo że wielokrotnie mówi się o Kapuścińskim jako o jednym z najczęściej tłumaczonych naszych autorów, rzadko poświęca się uwagę recepcji jego twórczości poza granicami ${ }^{3}$ albo przyczynom, które sprawiły, że reporter z Polski został uznany za intelektualistę pierwszej wielkości w Hiszpanii czy w Ameryce Łacińskiej, że jest autorem książki o statusie bestsellera, sprzedanej w Hiszpanii w sześciocyfrowym nakładzie, a jego twórczość figuruje na listach obowiązkowych lektur hiszpańskojęzycznych adeptów dziennikarstwa ${ }^{4}$.

\footnotetext{
${ }^{1}$ Wypowiedź R. Kapuścińskiego w filmie Druga Arka Noego, reż. P. Załuski, Telewizja Polska (Wrocław) 2000.

${ }^{2}$ R. Kapuściński, Podróże z Herodotem, Kraków 2004, s. 13.

${ }^{3}$ Warto zwrócić uwagę, że temat recepcji Kapuścińskiego często zajmuje badaczy zagranicznych uczelni. I tak na przykład Lidija Tanuševska jest autorką artykułu naukowego poświęconego recepcji Jeszcze dnia życia w Macedonii, Margreta Grigorova podjęła temat recepcji twórczości Kapuścińskiego w Bułgarii, Monika Woźniak zajmowała się odbiorem Kapuścińskiego we Włoszech, a recepcja Ryszarda Kapuścińskiego i jego książek w Hiszpanii została zbadana między innymi przez Aleksandrę Wiktorowską (2014) oraz Amelię Serraller Calvo (2015). Wśród polskich badaczy zajmujących się tematyką recepcji Kapuścińskiego za granicą warto wymienić Beatę Nowacką, autorkę między innymi artykułu „Ree-shard Kah-poosh-chin-skee” Kapuściński po angielsku oraz Li Yinan badającą recepcję literatury polskiej w Chinach (2015).

${ }^{4}$ Por. A. Wiktorowska, Ryszard Kapuścinski: visión integradora de un reportero. Clasificación, construcción y recepción de su obra [„Ryszard Kapuściński: integrujący obraz reportera. Klasyfikacja,
} 
Badaniom twórczości Ryszarda Kapuścińskiego poświęciłam studia magisterskie, podyplomowe i doktoranckie, a recepcja pisarza w Hiszpanii, Ameryce Łacińskiej i we Włoszech stała się jedną z części mojej pracy doktorskiej. Celem tego artykułu nie jest jednak wyczerpanie tematu, co z uwagi na ograniczone miejsce byłoby nierealne, a jedynie zasygnalizowanie pewnego fenomenu i zaproponowanie kilku możliwych tłumaczących go hipotez. Artykuł tym samym składa się z trzech części. Dwie pierwsze mają charakter historycznoliteracki, pokazuję w nich kolejno, jak twórczość Kapuścińskiego dotarła do Hiszpanii i do Ameryki Łacińskiej, jak była tam odbierana, kiedy i za sprawą jakich czynników reporterowi udało się odnieść sukces, a jego książki zaczęły cieszyć się popularnością. Trzecia część jest natomiast próbą teoretycznego ujęcia zagadnienia. Korzystając z teorii recepcji Hansa Roberta Jaussa i konceptu „horyzontu oczekiwań", staram się wyjaśnić, dlaczego dzieła Kapuścińskiego zaistniały właśnie w Hiszpanii, Ameryce Łacińskiej i we Włoszech ${ }^{6}$. Jeśli zaś chodzi o metodologię, podczas prowadzonych badań realizowałam kwerendy biblioteczne i archiwalne, analizowałam dostępne dokumenty oraz przeprowadziłam wiele wywiadów z osobami mogącymi rzucić światło na fenomen popularności reportera w danym kraju.

\section{Recepcja twórczości Ryszarda Kapuścińskiego w Hiszpanii}

Ale zadania tłumacza nie ograniczają się dziś do przełożenia tekstu na inny tekst, $\mathrm{z}$ jednego języka na drugi. Jako autor doznawałem zawsze i nadal odczuwam ich wielką życzliwość i pomoc na wielu polach i w różnych formach. Bo tłumacz to także ktoś jak agent literacki czy wręcz ambasador danego autora, a często i entuzjasta jego twórczości, ktoś, kto proponuje i poleca ją wydawcom, zwraca na niego uwagę miejscowych mediów, pisze recenzje i rekomendacje?

Na początku lat osiemdziesiątych XX wieku Agata Orzeszek ${ }^{8}$ wróciła z Polski do Barcelony - w której zamieszkała pod koniec 1977 roku - z egzemplarzem

budowa i recepcja jego twórczości”]. Barcelona, Universitat de Barcelona, 2014, s. 219-302.

${ }^{5}$ Tamże.

${ }^{6}$ Warto w tym miejscu zauważyć, że na języki włoski i hiszpański przetłumaczono najwięcej tytułów reportera.

${ }^{7}$ R. Kapuściński, Ttumacz - postać XXI wieku [w:] Podróże z Ryszardem Kapuścińskim, red. B. Dudko, Kraków 2007, s. 13.

${ }^{8}$ Agata Orzeszek jest autorką przekładów książek Ryszarda Kapuścińskiego na język hiszpański. Dotychczas w jej tłumaczeniu ukazały się kolejno: Szachinszach, Cesarz, Wojna futbolowa, Imperium, Heban, Jeszcze dzień zyycia, Lapidarium IV, Podróże z Herodotem, Busz po polsku, Ten Inny, Chrystus z karabinem na ramieniu oraz Czarne gwiazdy. Orzeszek jest też tłumaczką i redaktorką 
Cesarza. Książka, opublikowana w 1978 w wydawnictwie Czytelnik, cieszyła się już wówczas wielkim uznaniem nie tylko w Polsce, ale także za granicą. Tłumaczka założyła, że hiszpańskie wydawnictwa również się nią zainteresują. Przygotowała rekomendację i wysłała do kilku wydawców. Jednak ku jej rozczarowaniu żaden z nich nie wykazał zainteresowania. Orzeszek znała autora osobiście od początku lat siedemdziesiątych, kiedy to razem z jego córką studiowała iberystykę na Uniwersytecie Warszawskim", i od tamtej pory stała się przyjaciółką domu.

Choć przez pierwsze lata ze stron wydawnictw spotykały ją same odmowy, nie poddała się. W końcu sytuacja uległa zmianie, a zdarzyło się to w momencie, kiedy sukcesy zaczęła odnosić następna książka autora, Szachinszach. Było o niej głośno na Międzynarodowych Targach Książki we Frankfurcie i Jorge Herralde, barceloński wydawca, właściciel i wówczas prezes wydawnictwa Anagrama, przeczytawszy francuski przekład, zdecydował się ją wydać. On sam wspomina, że do międzynarodowej kariery autora przyczyniła się zwłaszcza Helen Wolff, słynna niemiecka wydawczyni, która uciekłszy przed nazistami do Stanów Zjednoczonych, założyła tam wraz z mężem Kurtem (pierwszym wydawcą Franza Kafki) wydawnictwo Pantheon:

Ostatniego dnia pracy w wydawnictwie [Helen Wolff - A.W.] otworzyła z prawdziwie niemiecką dyscypliną kopertę: tłumacze z języka polskiego wysłali jej rozdział Cesarza. Przeczytała go i „odkryła” Kapuścińskiego. Skontaktowała się z Drenką Willen, dzisiaj wielkie nazwisko w międzynarodowym świecie wydawniczym, która współpracowała z Harcourt Brace Jovanovich, wydawnictwo wydało książkę, podobnie jak Szachinszacha i Jeszcze dzień życia. Tłumaczenia ruszyły z kopyta: na niemiecki, na francuski, na włoski etc. W latach osiemdziesiątych Kapuściński stał się jedną z czołowych postaci czasopisma „Granta”, w epoce Billa Buforda (ożenionego wówczas, co ciekawe, z Polka) ${ }^{10}$.

W 1987 roku wydawnictwo Anagrama opublikowało Szachinszacha ${ }^{11}$, dwa lata później Cesarza ${ }^{12}$, w roku 1992 Wojnefutbolową $^{13}$, a w 1995 Imperium $^{14}$. Jednak $\mathrm{z}$ komercyjnego punktu widzenia publikacje okazały się porażką. Wspomina

książki El mundo de hoy. Autorretrato de un reportero, składającej się z fragmentów wywiadów i innych tekstów Ryszarda Kapuścińskiego, a także redaktorką tłumaczeń Podróży z Ryszardem Kapuścińskim na język hiszpański. W 2019 roku została odznaczona Nagrodą Translatorską dla Tłumaczy Ryszarda Kapuścińskiego.

${ }^{9}$ L. Moix, Kapuściński de cerca, „La Vanguardia”, 15.03.2007.

${ }^{10} \mathrm{~J}$. Herralde, Kapuściński lo ve [w:] Por orden alfabético, Barcelona 2006, s. 139-140 (jeśli nie zaznaczono inaczej, tłumaczenie pochodzi od autorki - A.W.).

${ }^{11}$ R. Kapuściński, El Sha o la desmesura del poder, tłum. A. Orzeszek, Barcelona 1982.

${ }^{12}$ Tenże, El Emperador, tłum. A. Orzeszek, R. Mansberger Amorós, Barcelona 1989.

${ }^{13}$ Tenże, La guerra del fútbol y otros reportajes, ttum. A. Orzeszek, Barcelona 1992.

${ }^{14}$ Tenże, El Imperio, tłum. A. Orzeszek, Barcelona 1995. 
o tym dziennikarz Arcadi Espada: „Herralde, nieskory do podobnych zwierzeń, opowiadał mi, że sprzedał 700 egzemplarzy Cesarza"15. I choć z ekonomicznego punktu widzenia nie było to opłacalne, wydawca wydawał kolejne tytuły autora nie tylko po to, żeby nie stracić praw do jego książek, ale także dlatego, że wydawnictwo Anagrama od samego początku kierowało się filozofią, żeby publikować nowe utwory swoich pisarzy, nawet jeśli poprzednie nie okazały się komercyjnym sukcesem ${ }^{16}$. We wspomnieniach Herralde odnotowuje:

Przez te wszystkie lata Kapuściński w Hiszpanii cieszy się niezwykłym uznaniem, ale niemal jedynie wśród najlepiej poinformowanych dziennikarzy, sprzedaż każdej z jego trzech pierwszych książek ledwo przekracza tysiąc egzemplarzy. I choć odwiedza Hiszpanię kilkakrotnie, w wielu gazetach pojawiają się wywiady i recenzje, dziennikarka Lala Gomà poświęca mu długi reportaż telewizyjny, choć wszyscy jak mantrę powtarzają „najlepszy reporter na świecie” (po dziesięcioleciach zjeżdżania kontynentów wzdłuż i wszerz, opisywania niezliczonych rewolucji i zamachów sta$\mathrm{nu}), \mathrm{w}$ dalszym ciągu jest autorem nieznanym. Sytuacja zaczyna się nieco polepszać wraz z Imperium, ale dopiero w 2000 roku, wraz z Hebanem, następuje prawdziwa eksplozja, a jej łatwo przewidywalnym skutkiem jest to, że książka staje się bestsellerem, jej czytelnicy zaś sięgają po wcześniejsze tytuły, które regularnie są wznawiane ${ }^{17}$.

Wystarczy odwiedzić wydawnictwo Anagrama, żeby potwierdzić te informacje. Teczki z wycinkami prasowymi i recenzjami wcześniejszych książek Kapuścińskiego zawierają po dziesięć lub dwanaście tekstów. Za kamień milowy można uznać rok 2000: to właśnie wówczas rozpoczyna się boom na Kapuścińskiego, pojawiają się dziesiątki wywiadów, recenzji, artykułów i opracowań. Podczas spotkania w siedzibie wydawnictwa z Aną Jornet, 4 marca 2011 roku, ówczesna rzeczniczka prasowa Anagramy pokazuje mi dane sprzedaży opublikowanych tytułów: Szachinszach wydany w Hiszpanii w 1987 roku do 2011 miał osiem wydań, Cesarz jedenaście, Wojna futbolowa zaledwie pięć, Imperium sześć, podczas gdy Heban był wznawiany dwadzieścia jeden razy.

Próbując odpowiedzieć na pytanie o przyczyny popularności Hebanu, najlepiej przytoczyć dwie kontrastujące ze sobą opinie. Zacznijmy od Arcadiego Espady, którego zdaniem:

naprawdę niezwykłe i znaczące jest to, że popularność Kapuścińskiego nie była związana z publikacją żadnej jego książki. Zbiegła się w czasie, owszem, z przekładem Hebanu, ale nie sądzę, żeby stało się tak za sprawą Hebanu ani żadnej z jego wcześniejszych książek, wszystkich lepszych od tej. Popularność ta była rezultatem

\footnotetext{
${ }^{15}$ A. Espada, Un tendal en Varsovia, „El Mundo”, 27.01.2007.

${ }^{16}$ Rozmowa z A. Jornet, Barcelona, 4.03.2011.

${ }^{17} \mathrm{~J}$. Herralde, dz. cyt., s. 140.
} 
przemiany autora w globalnego opiniotwórcę, zabierającego głos na takie tematy, jak pokój, równość, dobroć. Niewątpliwie niezwykle utalentowanego ${ }^{18}$.

\section{Z kolei Jorge Herralde uważa:}

Jakie były powody tego opóźnienia? Mogę zaproponować jedynie kilka chwiejnych hipotez. Szach był proamerykańską marionetką, jetsetterem już wtedy (albo od zawsze) zepsutym, u boku mającym Sorayę, zrzędliwą księżniczkę o smutnym obliczu, bezpłodną, od lat ukazującą się na okładkach „Hola” ${ }^{19}$ i w Marbelli ${ }^{20}$, a to sprawiało, że książkę natychmiastowo odrzucali (choć niesłusznie) potencjalni czytelnicy Kapuścińskiego. Jeśli zaś chodzi o cesarza Etiopii, Haile Selassie, był postacią równie odległą jak jego kraj i epoka, z których to powodów książka (choć jest to mój ulubiony Kapuściński) (...), też nie zaistniała. Z kolei o Związku Radzieckim i jego upadku opublikowano setki książek, prawie zawsze z niewielkim powodzeniem w Hiszpanii. Zainteresowanie, które we Francji wzbudzili Sołżenicyn czy chociażby dysydent Bukowski, nie ma nic wspólnego z przyjęciem ich w naszym kraju, o czym doskonale wiedzą ich ubolewający nad sytuacją wydawcy. Tutaj prasowe artykuły i telewizyjne wiadomości przeciętny czytelnik, cokolwiek miałoby to znaczyć, uważa za wyczerpujące. I nagle z Hebanem (...) nastąpił wybuch. Fascino africano? Któż to wie. Natomiast pewne jest, że to samo zadziało się w innych krajach, np. we Włoszech, o czym opowiadał mi Carlos Feltrinelli, albo we Francji, o czym zapewniał mnie Ivan Nabokov z wydawnictwa Plon; obaj wierni wydawcy i żarliwi czytelnicy Kapuścińskiego ${ }^{21}$.

W Polsce Heban cieszył się popularnością, jednak nie przyćmiła ona nigdy pozostałych książek autora. Był on już wówczas szeroko znany, nie tylko z reportaży książkowych, ale także prasowych, które ukazywały się, z przerwami, właściwie od drugiej połowy lat pięćdziesiątych XX wieku na łamach największych polskich dzienników i tygodników.

Na pewno natomiast warto przy tej okazji zauważyć, że Heban w twórczości Kapuścińskiego jest książką nową, inną od wcześniejszych. Nie jest to analiza władzy ani reportaż z pierwszej linii frontu, biografia dyktatora czy historyczny esej; to dzieło dużo bardziej antropologiczne w wymowie, w którym autor opisuje, jak w ciągu czterdziestu lat jego kontaktów z Afryką udało mu się zbliżyć do jej mieszkańców i poznać ich kultury. Ponadto, jak zauważa Magdalena Horodecka, „Niemal cały Heban został właściwie napisany w porządku odwracania

\footnotetext{
${ }^{18}$ A. Espada, dz. cyt.

19 „Hola” - popularny hiszpański kolorowy magazyn opowiadający o ludziach związanych z show-biznesem, w stylu polskiego „Życia na Gorąco”.

${ }^{20}$ Marbella - hiszpańska miejscowość na Costa del Sol nad Morzem Śródziemnym, kurort, w którym księżniczka Soraya kupiła dom.

${ }^{21} \mathrm{~J}$. Herralde, dz. cyt., s. 141.
} 
dotychczasowych hierarchii i wartościowań (biały reporter w kolejce po wodę, mieszkający w slumsach, czarny jako silniejszy, biały jako słaby)"22. Może dlatego książka wydaje się przeznaczona dla współczesnego czytelnika chcącego wyzwolić się od stereotypów i rasowych uprzedzeń. Jeśli dodamy do tego, że w 2000 roku do Hiszpanii, wraz z otwarciem granic, zaczęli napływać nowi imigranci, popularność książki o tej tematyce i kulturach, wzbudzających wówczas rosnące zainteresowanie, jest zrozumiała.

W Hebanie możemy też zauważyć początki filozofii Innego ${ }^{23}$. W kilku pierwszych zdaniach pełniących rolę prologu Kapuściński podkreśla: „Nie jest to więc książka o Afryce, lecz o kilku ludziach stamtąd, o spotkaniach z nimi, czasie wspólnie spędzonym"24. To właśnie z tej perspektywy poznajemy afrykański kontynent, nie z oficjalnych wizyt w pałacach, przez ważne figury czy wielką politykę, ale w trakcie wędrówek z koczownikami po pustyni albo w gościnie u chłopów z tropikalnej sawanny. To oni są Innymi, którzy pokazują Afrykę Kapuścińskie$\mathrm{mu}$, to wreszcie on jest Innym dla nich, jako że przyjęta przez autora kategoria zakłada wzajemność. To ich rzeczywistość obserwuje reporter, chcąc przekazać ją swoim czytelnikom.

Niezależnie od powodów popularności Hebanu to właśnie w tamtym okresie Kapuściński staje się w Hiszpanii „globalnym komentatorem”. Jak zauważa Orzeszek, kiedy pojawiał się w Barcelonie - obojętne czy był to 2002, 2005 czy 2006 rok - jeszcze przed jego przyjazdem rozdzwaniały się telefony. $\mathrm{Z}$ radia, z telewizji, umawiano się na wywiady, rozmowy, o dziennikarstwie, środkach masowego przekazu, globalizacji, terroryzmie, migracjach, cywilizacji, pracy reportera czy Trzecim Świecie. Zapraszano go na uniwersytety, proszono o wygłoszenie wykładu, poprowadzenie panelu ${ }^{25}$. Moix podsumowuje ten okres następująco:

Kontakty Kapuścińskiego z Hiszpanią charakteryzowała w ostatnich latach niezwykła intensywność. W 2002 roku wziął udział w festiwalu literackim Kosmópolis, organizowanym przez Centrum Sztuki Współczesnej w Barcelonie (CCCB). W 2003 roku pojawił się w Oviedo, gdzie odebrał nagrodę Premio Príncipe de Asturias w dziedzinie Komunikacji i Nauk Humanistycznych. W 2004 wrócił, żeby zasiąść w jury tejże nagrody. W roku 2005 przyjechał do Barcelony odebrać doktorat honoris causa ${ }^{26}$.

${ }^{22}$ M. Horodecka, Zbieranie gtosów, Gdańsk 2010, s. 134.

${ }^{23}$ Autor rozwinie ją w późniejszych latach w wykładach, które w 2007 roku złożą się na książkę Ten Inny. Por. R. Kapuściński, Ten Inny, Kraków 2007.

${ }^{24}$ R. Kapuściński, Heban, Warszawa 1998, s. 5.

${ }^{25}$ A. Orzeszek, Dreptania z(a) Kapuścińskim [w:] Podróże z Ryszardem Kapuścińskim..., dz. cyt., s. 119.

${ }^{26}$ L. Moix, dz. cyt. 
Do tej listy należałoby dodać jeszcze nagrodę Premio Liber Press de Girona z 2002 roku oraz nagrodę Fundacji Miguela Gila Moreno, której laureatem został w 2006 roku.

Jeśli natomiast przyjrzeć się towarzyszącym nagrodom wystąpieniom, warto zauważyć, że Kapuściński w Hiszpanii nie jest traktowany jak korespondent, reporter czy dziennikarz z Polski, ale jak świadek przemian, które miały miejsce w XX wieku: historyk, teoretyk, filozof, humanista, ekspert. Podczas wystąpienia na festiwalu literackim Kosmópolis mówi o roli literatury po upadku totalitaryzmu, o pracy korespondenta wojennego podczas konfliktów zbrojnych, o nowych wojnach „ekonomicznych”, o dzieciach-żołnierzach, minach przeciwpiechotnych, o nowych strategiach prowadzenia wojen „bez ofiar”, robotyzacji amerykańskiej armii ${ }^{27}$. Odbierając doktorat honoris causa w 2005 roku, mówi o spotkaniu z Innym jako wyzwaniu XXI wieku, o potrzebie zrozumienia drugiego człowieka, powołuje się na filozofów dialogu: Martina Bubera, Ferdinanda Ebnera, Gabriela Marcela, a przede wszystkim Emmanuela Lévinasa, wymienia również Bronisława Malinowskiego ${ }^{28}$. Zaproszony w 2005 roku do programu telewizyjnego La nit al dia w katalońskiej TV3 opowiada o wojnie w Iraku, wyborach w Iranie, Trzecim Świecie i sytuacji w krajach afrykańskich. Mówi o krajach muzułmańskich, obrazie Afryki przedstawianym w mediach masowego przekazu, o Ameryce Łacińskiej i wielkich zmianach na kontynencie, o Evo Moralesie, migracjach, Unii Europejskiej, Europie Wschodniej i Zachodniej. Odbierając nagrodę Fundacji Miguela Gila Moreno w 2006, opowiada o odpowiedzialności dziennikarza, który chce mówić prawdę, o opiniotwórczej roli mediów i konieczności pokazywania wszystkich możliwych punktów widzenia, a wreszcie wspomina korespondentów wojennych, którzy co roku giną, wykonując swój zawód.

Kapuściński w Hiszpanii nie jest jedynie autorem książek, ale jednym z czołowych intelektualistów XXI wieku, do którego zwracano się, by objaśnił świat.

\section{Recepcja Ryszarda Kapuścińskiego w Ameryce Łacińskiej}

Recepcja i popularność reportera w Ameryce Łacińskiej wyglądały nieco inaczej. Podstawowa różnica polegała na tym, że w przypadku Ameryki Łacińskiej najpierw zaistniał sam reporter jako osoba, poprzez swoje kontakty, szczególnie dziennikarskie, a dopiero później jego książki, które (z wyjątkiem trzech tytułów) trafily do czytelników w tym samym czasie co do hiszpańskich.

Kapuściński przyjechał do Ameryki Łacińskiej jako korespondent PAP-u w 1967 roku. I pozostał tam do 1972 roku. Przez ten czas zjeździł

${ }^{27}$ R. Kapuściński, El cambio de función de la literatura después de la caída del totalitarismo, CCCB, Barcelona, 14.12.2002 (nagranie).

${ }^{28}$ Tenże, El encuentro con el Otro como reto del siglo XXI, Universitat Ramon Llull, Barcelona, 17.06.2005. 
kontynent, stając się świadkiem wielu zamieszek i zamachów stanu. $\mathrm{Z}$ tych podróży zrodziły się jego trzy książki poświęcone Ameryce Łacińskiej: Dlaczego zginat Karl von Spreti (opublikowana w Polsce w 1970), Chrystus z karabinem na ramieniu (1975) i Wojna futbolowa (1978). Warto zauważyć, że pierwszym wydawnictwem hiszpańskojęzycznym, które go wydało, było meksykańskie Nueva Política, gdzie w 1977 roku ukazała się La guerra de Angola, a więc Jeszcze dzień życia, w przekładzie Marii Dembowskiej, tłumaczki również pierwszej wersji hiszpańskojęzycznego Cesarza, opublikowanego w 1980 przez meksykańskie wydawnictwo Siglo XXI ${ }^{29}$, w tym samym roku Uniwersytet Veracruzana wydat Las botas, czyli Wojne futbolowa, w thumaczeniu Gustawa Kolińskiego i Mario Muñoza ${ }^{30}$.

Te pierwsze przekłady są najprawdopodobniej owocem prywatnych kontaktów autora, który, przypomnijmy, w 1968 roku zamieszkał w Meksyku. Po wyjeździe z Ameryki Łacińskiej będzie tam kilkakrotnie wracał. W 1979 roku wygłosi serię wykładów w Caracas, w 2000 roku, na zaproszenie Uniwersytetu Iberoamericana de México, będzie uczestniczył w sympozjum na temat dziennikarstwa i nowych technologii, promując jednocześnie Heban. W roku 2001 na zaproszenie Gabriela Garcíi Márqueza poprowadzi warsztaty zorganizowane przez Fundación para un Nuevo Periodismo Latinoamericano (FNPI), a w 2002 weźmie udział w promocji książki Los cínicos no sirven para este oficio („To nie jest zawód dla cyników"), tym razem na Universytecie Veracruzana, i wygłosi cykl wykładów w Buenos Aires. To właśnie w tamtym okresie, konkretnie we wrześniu 2002 roku, powie w jednym z wywiadów:

Darzę Meksyk głębokim uczuciem, dlatego, że mieszkałem tutaj przez cztery lata. Przyjechałem w 1968 roku i dużo podróżowałem; a potem, po wyjeździe w 1972 roku, wiele razy wracałem. Jest to jeden z najbliższych mojemu sercu krajów i jeden z najlepiej mi znanych. Meksyk nie jest dla mnie abstrakcją. Wielokrotnie o nim pisałem. W Wojnie futbolowej. W moim Lapidarium. Czuję się obywatelem Meksyku ${ }^{31}$.

Kapuściński dotarł więc do Meksyku, zanim usłyszano o nim w Hiszpanii czy w Stanach Zjednoczonych, a stało się tak „za sprawą koneksji, które miał z meksykańskimi dziennikarzami”. Paco Ignacio Taibo II zauważa również, że „dla większości z nas, którzy w tamtych latach zdobywaliśmy dziennikarskie szlify, wpływ Kapuścińskiego był niepodważalny"32.

${ }^{29}$ Por. G. Bąk, Kapuściński, Ryszard [w: Diccionario histórico de la traducción en España, Madryt 2009, s. 642.

${ }^{30}$ Por. V. Roura, $Y$ critica, „El Financiero”, 24.01.2007.

${ }^{31}$ M. Mateos-Vega, Murió Kapuściński, reconocido como el más grande reportero de la historia, „La Jornada”, 24.01.2007.

${ }^{32}$ P.I. Taibo II, Su influencia, fundamental para nosotros, „La Jornada”, 24.01.2007. 
Jednak Meksyk nie był pierwszym odwiedzonym przez reportera krajem Ameryki Łacińskim, było nim Chile. Jak wspomni po latach w Wojnie futbolowej:

Jesienią roku 1967 wyjechałem na pięć lat do Ameryki Łacińskiej. Moim pierwszym miastem było Santiago de Chile, dziwaczny twór architektoniczny, składający się z miniatury Manhattanu, otoczonej morzem kamieniczek w stylu przewrotnej i kapryśnej secesji hiszpańskiej, z komfortowych i ekskluzywnych dzielnic w rodzaju Los Leones, Apoquindo i Vitacury oraz niekończących się drewnianych, szałasowych przedmieść zwanych tutaj callampas, a zamieszkanych przez proletariat, biedotę, a także wielkie lumpiarstwo ${ }^{33}$.

W Santiago reporter znów czuje się głuchy i niemy, tak jak przytrafiło mu się to w Indiach podczas jego pierwszej podróży. Powód: brak znajomości języka. Umawia się z przełożonymi w PAP-ie, że przez pierwsze trzy miesiące nie będzie musiał niczego pisać i przede wszystkim zajmie się nauką hiszpańskiego ${ }^{34}$. W 1968 roku w Instytucie Spraw Międzynarodowych w Santiago wygłosi odczyt poświęcony Polsce, który zostanie uznany za dowód, że udało mu się nauczyć języka na tyle, że może się w nim porozumieć. W kwietniu tego samego roku, zmuszony przez chilijski rząd do wyjazdu z powodu artykułu uznanego za ingerencję w wewnętrzne sprawy kraju ${ }^{35}$, Kapuściński jedzie do Peru, które oferuje mu wizę, i tam, w hotelu w Limie, tłumaczy na język polski Dziennik z Boliwii Ernesta Che Guevary, co poniekąd można uznać za kolejną próbę związaną z nauką hiszpańskiego. Jego przyjaciele pamiętają lekki latynoamerykański zaśpiew, kiedy mówił po hiszpańsku. Zresztą kwestia językowa okazuje się decydującym czynnikiem w wypadku recepcji reportera w krajach hiszpańskojęzycznych, dlatego że umożliwia mu bezpośredni kontakt zarówno z ludźmi, o których pisze, jak i z innymi dziennikarzami czy studentami.

Jednym z tych dziennikarzy był bez wątpienia Luis Suárez, którego Kapuściński wymienia na stronach Wojny futbolowej i który namówił go wtedy, żeby poleciał do Hondurasu, bo będzie wojna ${ }^{36}$. Jak wspomina Juan Villoro, Suárez dziennikarz tygodnika "Siempre” i nauczyciel całego pokolenia dziennikarzy polecał wszystkim Kapuścińskiego ${ }^{37}$, którego twórczość niezwykle cenił. Całe pokolenia wychowały się więc, czytając Las botas (pierwsze tłumaczenie Wojny futbolowej), Roberto Herrscher opowiada nawet o przekazywanych w środowisku kopiach kopii samego reportażu o takim samym tytule ${ }^{38}$.

\footnotetext{
${ }^{33}$ R. Kapuściński, Wojna futbolowa, Warszawa 2010, s. 162.

${ }^{34}$ A. Domosławski, Kapuściński non-fiction, Warszawa 2010, s. 243.

35 Tamże, s. 244-245.

${ }^{36}$ R. Kapuściński, Wojna futbolowa, dz. cyt., s. 167-170.

${ }^{37}$ Wywiad z J. Villoro, Meksyk, 19.02.2013.

${ }^{38}$ Wywiad z R. Herrscherem, Barcelona, 18.01.2013.
} 
Szczególny związek łączący Kapuścińskiego z Meksykiem rozszerzał się stopniowo na całą Amerykę Łacińską i w drugiej edycji warsztatów organizowanych przez Fundación para un Nuevo Periodismo Iberoamericano chciały już wziąć w nich udział setki studentów. Zdaniem ówczesnego dyrektora fundacji Jaime Abello: „Na warsztaty z innymi mistrzami zawodu aplikuje zwykle 100-120 dziennikarzy. Na warsztaty z Kapu przychodziło 180-200 wniosków. Ostatecznie w warsztatach bierze udział piętnastka wybranych"39.

Owocem wspomnianych warsztatów jest opublikowana w 2003 roku książka Los cinco sentidos del periodista („Pięć zmysłów dziennikarza”) ${ }^{40}$, która w 2013 doczekała się przekładu na język polski ${ }^{41}$. Innym, równie namacalnym, jest fakt, że wielu z jego uczniów pracuje obecnie w najważniejszych dziennikach w swoich krajach. W Ameryce Łacińskiej często mówi się, że łatwo rozpoznać wśród piszących dziennikarzy tych, którzy wzięli udział w warsztatach i poznali mistrza; podobno piszą znacznie lepiej niż inni.

Artur Domosławski w jednym z artykułów ochrzcił ten fenomen „kapumanią”, a nawet „kapumafią”, odnosząc się do autorytetu i popularności, jaką Kapuściński cieszył się w krajach Ameryki Łacińskiej ${ }^{42}$, gdzie był słuchany jak ktoś, kto potrafi uczynić świat zrozumiałym, poszerzyć perspektywę, dać klucz do wiedzy. Domosławski wspomina, że kiedy przyjechał do Meksyku, ktoś wręczył mu teczkę z niezliczonymi artykułami dotyczącymi wizyty Kapuścińskiego z 2001 roku: „Czegóż tam nie było? Dwadzieścia, a może czterdzieści pięć artykułów, esejów, wywiadów, notatek, refleksji, impresji... Z lewa, z prawa, z góry, z dołu. Miało się wrażenie, że przyjechał nie reporter, nie pisarz, ale połączenie intelektualnej świetności, religijnego guru i pop gwiazdy" ${ }^{\text {‘ }}$.

Wystarczy rzucić okiem na opinie studentów, którzy ocenili warsztaty z reportażu, organizowane przez FNPI w mieście Meksyk w marcu 2001 roku. Wśród kilkunastu opinii, wszystkich w podobnym guście, możemy przeczytać:

Julio Villanueva Chang (Peru): Od pana K. nauczyłem się przyglądać światu z mniejszym cynizmem, podnosić walizki z mniejszą powagą i dramatyzmem, mniej mrugać, ślęcząc nad książkami bladym świtem; od pana K. nauczyłem się też, że samotność może być błogosławieństwem dla reportera, że na wojnach przegrywamy wszyscy i że większość z nas, dziennikarzy, zamienia się w najemników, że na tym świecie jest coraz mniej dziennikarzy dających świadectwo (...) i że prawdziwą przyjemnością jest móc pisać, a nie być w telewizji, i żeby czasem coś zyskać, trzeba stracić.

\footnotetext{
${ }^{39}$ A. Domosławski, Kapuściński non-fiction, dz. cyt., s. 524.

${ }^{40} \mathrm{R}$. Kapuściński, Los cinco sentidos del periodista, México 2003.

${ }^{41}$ Tenże, To nie jest zawód dla cyników, Warszawa 2013.

${ }^{42}$ A. Domosławski, Kapumania, kapumafia, „Gazeta Wyborcza”, 17.05.2005.

${ }^{43}$ Tamże.
} 
Carlos Alberto Giraldo (Kolumbia): Kapuściński jest największym czarownikiem plemienia reporterów.

Graciela Machkofsky (Argentyna): Warsztaty reportażu z Kapuścińskim były wspaniałe z wielu powodów. Kapuściński. Jego opowieści i rady, poza tym, że arcyciekawe, pobudziły jeszcze moją miłość do dziennikarstwa i naprowadziły mnie na rozwiązania niektórych osobistych problemów.

Laura Weffer (Wenezuela): Oto z największą pokorą mówi człowiek, który po prostu żyje dziennikarstwem. I hojnie, jak tylko on potrafi, dzieli się z nami swoimi doświadczeniami, a my chciwie spijamy każde jego słowo ${ }^{44}$.

Warto wspomnieć, że Julio Villanueva Chang jest redaktorem naczelnym i założycielem czasopisma „Etiqueta Negra”; Carlos Alberto Giraldo jest reporterem, naczelnym działu interwencyjnego w „El Colombiano”, Graciela Mochkofsky jest autorką kilku książek (między innymi Timerman czy Los farsantes), Laura Weffer, dziennikarka „El Nacional”, w 2006 roku dostała nagrodę za najlepsze dziennikarskie śledztwo za opisaną sprawę korupcji w Ameryce Łacińskiej i na Karaibach.

Wśród „kapumaniaków” figurują najwięksi pisarze i intelektualiści Ameryki Łacińskiej: Domosławski zalicza do tego grona Enrique Krauze, Carlosa Monsiváisa, Gabriela Zaida, Carlosa Fuentesa, Gabriela Garcíę Márqueza ${ }^{45}$. Ten ostatni pojawił się w 2001 roku na prowadzonych przez Kapuścińskiego warsztatach. „I pierwszym, co powiedział Gabo, było: Oto prawdziwy mistrz. A Kapu odpowiadał: Nie, nie, nie. W żadnym wypadku!". Arturo Cano wspomina też, że w czasie warsztatów Kolumbijczyk zadeklarował: „Jestem najwnikliwszym, najstarszym i najwierniejszym czytelnikiem Kapuścińskiego" ${ }^{46}$.

Jakie mogą być przyczyny popularności Kapuścińskiego w Ameryce Łacińskiej? José Carreño Carlón podkreśla, że Kapuściński pisał dokładnie na odwrót niż dominująca prasa, „która zamęczała nas wizją świata i ludzi proponowaną przez rzeczników wszelkiej maści władzy, czy to politycznej, czy religijnej, ekonomicznej lub kulturowej ${ }^{47}$.

Uczestnicy warsztatów natomiast przede wszystkim cenili jego opinie, które wydawały się niemal zaprzeczeniem dziennikarstwa, jako że - jak zaznacza jedna z dziennikarek biorących w nich udział, dzisiaj pracująca w „Excelsior” i pisząca książki - jego nauki kontrastowały z tym, czego uczy się na uniwersytetach:

${ }^{44}$ Ryszard Kapuścinski: reportero del tercer mundo, red. R. Corredor Cure, Ó. Escamilla V., „Sala de Prensa”, listopad 2001, nr 27, http://www.saladeprensa.org/art287.htm, dostęp: 2.02.2014.

${ }^{45}$ A. Domosławski, Kapumania, kapumafia, dz. cyt.

${ }^{46}$ A. Cano, El adiós de un cazador furtivo, „La Jornada”, 24.01.2007.

${ }^{47}$ J. Carreño Carlón, Las "fuentes” de Kapuściński y las de los medios mexicanos, „La Crónica”, 24.01.2007. 
Nigdy nie przekraczać cudzych granic, unikać sławy i pieniędzy, nigdy nie stracić żadnego przyjaciela przez artykuł, wchodzić w buty człowieka, z którym przeprowadza się wywiad, a motorem do działania uczynić miłość do bliźniego, zostawić ego na boku, bo dziennikarz, który dużo wie, jest predestynowany, żeby ponieść $\mathrm{klęskę}^{48}$.

Domosławski wyjaśnia przyczyny „kapumanii” w podobnym tonie, podkreślając, że widzieli w nim człowieka mówiącego z autentycznego osobistego doświadczenia, który nie prowadzi krucjat, a ponadto dąży do spotkania i zrozumienia Innego ${ }^{49}$. Prawdopodobnie to właśnie przyniosło mu taką popularność i uznanie w Ameryce Łacińskiej.

Warto w tym miejscu dodać, że Ameryka Łacińska była dla Kapuścińskiego miejscem szczególnym. Reporter niejednokrotnie przyznawał w wywiadach:

Źle się czuję w warunkach stabilizacji. Moja szkoła życia to wojna, ruch, konflikty, napięcia, dużo zdarzeń. Dlatego nie interesuje mnie Europa. Nie potrafiłbym teraz napisać słowa o Paryżu, chociaż byłem tam parę razy. Potrzeba mi silnych wrażeń, muszę coś przeżywać, bym mógł napisać reportaż ${ }^{50}$.

Pierwszy raz, kiedy znalazł się w Ameryce Południowej, minęły zaledwie dwa miesiące od śmierci Ernesta Che Guevary. Większość problemów, z którymi się zetknął, nie była mu obca, dlatego że były podobne do tych, z którymi mierzył się w Afryce: słabość państwa oraz nierówności społeczne i etniczne. W nich widział dwa źródła kłopotów i problemów Latynoamerykanów. Od momentu, w którym się tam znalazł, był świadkiem konfliktów zbrojnych, wojen, rewolucji, zamachów stanu. Ameryka Łacińska stała się jego drugim domem (a właściwie trzecim, jeśli weźmiemy pod uwagę, że drugim była Afryka).

Wracał tam kilka razy, w latach dziewięćdziesiątych i na początku dwutysięcznych, zawsze zainteresowany tamtejszymi przemianami politycznymi i społecznymi. I tak na własne oczy widział „rewolucję demokratyczną”, przebudzenie mniejszości etnicznych. Wszystkie te fenomeny nie były dla niego nowe i znał ich przyczyny. Jednocześnie te ruchy żądały znacznie więcej, niż udało się osiągnąć w krajach afrykańskich. Kapuściński miał nadzieję, że nieczujący już strachu Latynoamerykanie, zdający sobie sprawę, że epoka krwawych konfrontacji dobiegła końca, domagający się sprawiedliwości i równości mieli znacznie więcej szans, żeby to osiągnąć. Represyjna władza wojskowych reżimów lat sześćdziesiątych i siedemdziesiątych przeszła do historii, a nierówność, która rodziła frustrację i rezygnację, nagle przerodziła się w fale protestów i buntów, które miały

${ }^{48}$ M. Turati, Entraba por la puerta de la cocina, „Excelsior”, 24.01.2007.

${ }^{49}$ A. Domosławski, Kapumania, kapumafia, dz. cyt.

${ }^{50} \mathrm{R}$. Kapuściński w rozmowie z W. Wiśniewskim, Być dla siebie surowym [w:] Autoportret reportera, red. K. Strączek, Kraków 2003, s. 44. 
na celu chęć zmiany. Dla Kapuścińskiego nie była to jedynie kwestia ruchów w konkretnych krajach Trzeciego Świata, tylko przykład dla innych: „XXI stulecie będzie wiekiem Ameryki Łacińskiej! Koniec krwawych wojen, dyktatur, prawie wszędzie nastała demokracja. Ten kontynent jest w trakcie pokojowej rewolucji, staje się laboratorium nowych form społecznych, kulturalnych, miejscem eksperymentów" ${ }^{\prime 1}$.

Guadalupe Alonso i José Gordon pamiętają słowa, które wygłosił w 2001 roku, kiedy zapatyści wjechali na Zócalo w Meksyku: „Wszystko zaczęło się od partyzantki, od walk, a skończyło niezwykle pozytywnym ruchem społecznym" 52 . W tych zmianach, w dekolonizacji kulturowej, widział Kapuściński przyszłość Ameryki Łacińskiej.

\section{ABC popularności Ryszarda Kapuścińskiego}

W czasie prowadzonych badań w Hiszpanii i Meksyku w latach 2012-2014, podczas wywiadów z tłumaczami, wydawcą, reporterami i wykładowcami wydziałów dziennikarstwa ${ }^{53}$, łatwo było skonstatować, że Kapuściński miał wielu naśladowców, miłośników i czytelników zarówno w Hiszpanii, jak i w Ameryce Łacińskiej. Niemniej, jak starałam się pokazać, recepcja jego twórczości zależna była od rozbieżnych czynników: jeśli w Hiszpanii popularność przyniosły Kapuścińskiemu przede wszystkim jego książki, to w Ameryce Łacińskiej początkowo przeważyły kontakty osobiste i ogromne uznanie, jakim cieszył się ze strony dziennikarzy, studentów i uczestników warsztatów. Niemniej w obu tych miejscach był jednogłośnie uważany za intelektualistę trafnie objaśniającego problemy i wyzwania XXI wieku.

Przy analizie zebranych danych jed ną z pomocnych teorii okazała się teoria recepcji i koncept „horyzontu oczekiwań” Hansa Roberta Jaussa, od których zależy, jak publiczność danej epoki przyjmuje i ocenia dane dzieło literackie. Horyzont oczekiwań będący „specyficzną dyspozycją publiczności, poprzedzającą reakcję psychologiczną, jak również subiektywne zrozumienie poszczególnego czytelnika" ${ }^{4}$ zależy od kilku czynników. Jednym z nich są znane formy lub immanentna poetyka gatunku ${ }^{55}$, do którego zalicza się dane dzieło. Uprawiany przez Kapuścińskiego gatunek, który w swojej pracy doktorskiej nazwałam

${ }^{51}$ R. Kapuściński w rozmowie z A. Domosławskim, Wiosna ludów latynoskich, „Gazeta Wyborcza”, 7.04.2001.

${ }^{52}$ G. Alonso, J. Gorgon, Un periodista sin fronteras, „Reforma”, 28.01.2007.

53 Tłumacze: Agata Orzeszek, Maria Dembowska, Jerzy Sławomirski; wydawca: Jorge Herralde; reporterzy: Llàtzer Moix, Bru Rovira, Juan Villoro; wykładowcy dziennikarstwa: Alberto Chillón, Roberto Herrscher.

${ }^{54}$ H.R. Jauss, Historia literatury jako wyzwanie rzucone nauce o literaturze (fragmenty), thum. R. Handke, „Pamiętnik Literacki” 1972, t. LXIII, z. 4, s. 277.

55 Tamże, s. 279. 
reportażem integrującym ${ }^{56}$, mógł więc mieć zasadniczy wpływ na recepcję jego twórczości w wymienionych krajach, jako że sposób jego pisania ma dużo wspólnego z latynoamerykańską crónica (przypominającą polski reportaż). W związku z tym jego reportaże czytane przez hiszpańskojęzycznych czytelników ewokowały w ich świadomości znany im dobrze z wcześniejszych tekstów reporterskich horyzont oczekiwań i reguł gry.

Z drugiej strony odbiór dzieła przez czytelników zależy również od dystansu estetycznego, to jest „odległości dzielącej dany pierwotnie horyzont oczekiwań i nowo pojawiające się dzieło, którego przyjęcie może spowodować »zmianę horyzontu « w rezultacie negacji utrwalonych doświadczeń albo uświadomienia wypowiedzianych po raz pierwszy" ${ }^{\text {"57 }}$, który zdaniem Davida Viñasa pozwala w sposób najbardziej obiektywny oszacować oryginalność danego dzieła ${ }^{58}$. Większość moich rozmówców zwróciła uwagę na fakt, że w Kapuścińskim łączą się trzy osoby, z jednej strony mamy, jak ujął to Llàtzer Moix, czytelnika, historyka, kogoś, kogo moglibyśmy określić myszą biblioteczną, z drugiej człowieka czynu, zaangażowanego w opis rzeczywistości, z trzeciej natomiast, literata, który przetwarza zebrany materiał, chcąc nadać mu kształt. Zarówno Moix, jak i Villoro zaznaczyli, że ten sposób pisania uważają za nowatorski. A zatem, pisarstwo Kapuścińskiego z jednej strony przypomina dobrze znany w kręgach hiszpańskojęzycznych gatunek, z drugiej zaś dodaje do niego nowy, nieznany wcześniej wymiar, a więc przekracza narracyjnie formułę reportażu, sięgając po rozwiązania formalne i językowe do literatury.

Biorąc pod uwagę, że Kapuścińskiemu udało się przekroczyć granicę oddzielającą dziennikarstwo od literatury już w latach sześćdziesiątych XX wieku, można by założyć, że pośród krajów, w których cieszy się największą popularnością, powinny znaleźć się Stany Zjednoczone, kolebka New Journalism, a więc gatunku opowiadającego się w tym samym czasie za podobnym typem narracji. Tak się jednak nie stało. Dlaczego?

Żeby odpowiedzieć, musimy odwrócić wyjściowe pytanie. Zamiast koncentrować się na kwestii, dlaczego w tych, a nie innych miejscach Kapuściński odniósł znaczący sukces, zastanówmy się: co łączy Hiszpanię i Amerykę Łacińską poza wspólnym językiem? Co różni je od innych krajów? I na ile te podobieństwa łączą się z samym autorem i jego twórczością.

Pierwszym wspólnym wyznacznikiem są odkrycia geograficzne, które jednocześnie mogłyby wyjaśnić, dlaczego Heban, zarówno we Włoszech, jak i w Hiszpanii, cieszy się tak wielką popularnością. Il fascino africano, fascynacja Afryką, na którą powołuje się Jorge Herralde, wraz z ciekawością świata oraz także fascynacją podróżami, spotykają się z ogromnym zainteresowaniem czytelników.

${ }^{56}$ Por. A. Wiktorowska, dz. cyt., s. 213-220.

${ }^{57}$ H.R. Jauss, dz. cyt., s. 280.

${ }^{58} \mathrm{D}$. Viñas, Los géneros literarios [w:] Teoría de la literatura y literatura comparada, red. J. Llovet, Barcelona 2005, s. 282. 
Kapuściński pełni tutaj funkcję Marco Polo lub innego odkrywcy: przybliża swoim czytelnikom nieznane miejsca, interesujące również z historycznego punktu widzenia, tak jak Związek Radziecki dla Włochów czy Afryka dla Hiszpanów i Katalończyków.

Drugim jest tradycja kolonialna. Hiszpania ostatnie zamorskie kolonie utraciła w 1898 roku, podczas gdy Włochy, afrykańskie, dopiero w roku 1947, na mocy traktatu paryskiego. Ameryka Łacińska natomiast jest kontynentem naznaczonym kolonializmem; dlatego bardziej niż z tradycją kolonialistów związana jest $\mathrm{z}$ tradycją krajów skolonializowanych.

Kapuściński w swojej twórczości mówi dużo o kolonializmie. Nigdy natomiast nie odwołuje się do kolonializmu hiszpańskiego czy włoskiego. W Ameryce Łacińskiej zwraca jego uwagę amerykański imperializm, tak samo jak na Bliskim Wschodzie, w Afryce z kolei opisuje panowanie Anglików, Francuzów, Belgów i Portugalczyków, obecnych tam w latach sześćdziesiątych XX wieku, kiedy $i$ on się tam znalazt. Uwagę reportera przykuwają wszelkie formy imperializmu, a to zazębia się z kolejnym ważnym czynnikiem: ideologią.

Zarówno literacka, jak i reporterska wielkość Kapuścińskiego ma swoje korzenie w wyznawanych przez niego wartościach, w szacunku, którym darzy zwykłych, nierzadko ubogich, ludzi. Jego spojrzenie rzadko przykuwają prezydenci i władcy czy politycy, natomiast często oddaje głos ludziom zmarginalizowanym, którzy są go pozbawieni.

Ta optyka jest widoczna już chociażby w pierwszej afrykańskiej książce $C z a r-$ ne gwiazdy, w której reporter otwarcie szydzi z kolonów, poświęcając całą swoją uwagę rdzennym mieszkańcom Afryki. Cechą charakterystyczną jego tekstów jest troska o ludzi znajdujących się w gorszym położeniu. A to z kolei mogłoby, przynajmniej częściowo, wyjaśnić jego popularność wśród intelektualistów hiszpańskich, latynoamerykańskich i włoskich, związanych z heglowską lewicą.

Ponadto pierwszymi tytułami wydanymi w Hiszpanii są Szachinszach i $C e-$ sarz, które zyskują uznanie w wąskich kręgach intelektualistów i dziennikarzy. I tutaj również istotny jest fakt, że dwie pierwsze opublikowane w Hiszpanii książki stanowią dyptyk o despotycznej władzy, a ukazują się w kraju, w którym dyktatura zakończyła się wraz ze śmiercią Franco dopiero w 1975 roku. To samo dotyczy Ameryki Łacińskiej, gdzie postać kacyka była dobrze znana.

Równie ważna jest filozofia Innego, uznana przez moich rozmówców za jedną z wyróżniających cech pisarstwa Kapuścińskiego, który zwraca uwagę na wykluczonych i, jak na człowieka wyedukowanego w duchu marksistowskim przystało, solidaryzuje się z klasami ciemiężonymi.

Warto przy tej okazji zwrócić uwagę na zajmowane przez autora stanowisko. Będąc reporterem zza żelaznej kurtyny w czasach Zimnej Wojny, Kapuściński nie był poddany tej samej kontroli, jaką sprawowały wielkie media zachodnie. Często pisał o krajach, do których nie dotarł jeszcze żaden reporter zza zachodniej strony żelaznej kurtyny, a choćby dotarł, poruszałby się, zgodnie z prawami czystej logiki, w kręgach kolonialistów, a nie kolonizowanych, a przez to nigdy 
nie uzyskałby tych samych informacji, co Kapuściński; nie jest tym samym obserwować rzeczywistość z punktu widzenia silnego, co z perspektywy „skrzywdzonych i poniżonych", parafrazując Dostojewskiego.

W latach sześćdziesiątych XX wieku w Polsce popularny był obrazek satyryczny przedstawiający głowę o dwóch twarzach. Jedna miała zasłonięte oczy i wolne usta, druga zasłonięte usta i wolne oczy. Symbolika była jasna: oto ci, którzy widzą, nie mogą nic mówić, a ci, którzy mogą mówić, nie widzą, co dzieje się wokół nich. Obrazek perfekcyjnie oddawał paradoksalną sytuację, w której znajdował się dziennikarz: ten z kraju zachodniego musiał podporządkować się linii ideologicznej ośrodka komunikacji, dla którego pracowal, a ten ze Wschodu - cenzurze. Kapuściński nie był dziennikarzem zachodnim. Był Europejczykiem, którego rdzenni mieszkańcy Afryki uważali za Afrykańczyka ${ }^{59}$, pochodził z dalekiego „białego” kraju, który nie miał kolonii, „a był taki czas, kiedy sam był kolonią" ${ }^{\circ}$. Wreszcie, jak zauważa Jan J. Milewski, był naocznym świadkiem dekolonizacji Afryki i jednym z pierwszych autorów - włączając Afrykanów - „który opisał patologię nowych elit rządzących i zagrożenia dla przyszłości nowych państw" ${ }^{61}$.

Podobny sposób widzenia i rozumienia świata mieli hiszpańscy, włoscy i latynoamerykański intelektualiści (i studenci nauk humanistycznych). W Hiszpanii, kraju, który przeżył dyktaturę generała Franco; we Włoszech, w których niejednokrotnie dochodził do głosu faszyzm, czy wreszcie w Ameryce Łacińskiej, która w latach siedemdziesiątych walczyła z uciskiem ze strony wojskowych reżimów.

Trzecią i zarazem ostatnią cechą łączącą te regiony jest przynależność do najbardziej katolickich krajów na świecie. To nie przypadek, że we Włoszech Kapuściński był często porównywany z Karolem Wojtyłą, dlatego że filozofia Innego, decyzja i dążenie, żeby „dać głos ubogim”, nie tylko odsyła nas do etyki filozoficznej, ale także do etyki chrześcijańskiej, która jest częścią doktryny społecznej Kościoła.

Kwestia socjalna, a zwłaszcza sytuacja robotników, była jednym z centralnych zmartwień papieskich od czasów encykliki Rerum novarum Leona XIII. I choć ta ostatnia została ogłoszona w odpowiedzi na ówczesną sytuację polityczną (rosnący w siłę blok wschodni) i była wymierzona w socjalizm (sprzeciwiając się wizji sprawiedliwości socjalistycznej, papież opowiadał się przeciwko zniesieniu własności prywatnej i wprowadzeniu wspólnej oraz przeciw walce klas), to wyraźnie podkreśla się w niej, że każdy kraj katolicki powinien roztoczyć opiekę nad wszystkimi swoimi obywatelami, papież przedstawił w niej: „wizję poprawy bytu opartą na poszanowaniu prawa naturalnego, w tym na poszanowaniu podstawowych praw człowieka i jego godności, na sprawiedliwym podziale dóbr" ${ }^{2}$.

${ }^{59}$ R. Kapuściński, Busz po polsku, Warszawa 2008, s. 126.

${ }^{60}$ Tamże, s. 128.

${ }^{61}$ J.J. Milewski, Gdyby cata Afryka... - dzisiaj. Postowie [w:] R. Kapuściński, Gdyby cata Afryka, Warszawa 2011, s. 384.

${ }^{62}$ A. Wróbel, Encyklika "Rerum novarum” - Magna charta katolickiej nauki spotecznej, „Studia Teologiczno-Historyczne Śląska Opolskiego” 2013, nr 33, s. 325. 
Sto lat później Jan Paweł II w Centissimus annus również mówił o odpowiedzialności za robotników i najbiedniejszych. Uprzedzał o niebezpieczeństwach kapitalizmu (i socjalizmu), podkreślając, że całe masy ludzi żyją w ekstremalnej biedzie i nie można zostawić ich samych sobie z myślą, że siły rynku wszystko rozwiążą. Papież kładł tym samym nacisk na pozorną dekolonizację wielu krajów uznawanych za niezależne, których ekonomia w dalszym ciągu była zależna od wielkich międzynarodowych koncernów, a ich polityka często także pozostawała pod kontrolą zewnętrzną. We wcześniejszej encyklice, Sollicitudo rei socialis, zaatakował politykę imperialistyczną; przypominając, że narody silniejsze i bogatsze powinny czuć się moralnie odpowiedzialne za innych, dlatego że tylko w ten sposób może wykształcić się międzynarodowy system, w którym wszyscy będą sobie równi. Papież podkreślał tym samym konieczność solidarności narodów w obliczu globalnych problemów ${ }^{63}$.

Urodzony w jednym z najbardziej katolickich krajów na świecie reporter podzielał część chrześcijańskich wartości, a wyznawana przez niego etyka została naznaczona katolicyzmem. Dlatego też zarówno w Hiszpanii, Włoszech, jak i w Ameryce Łacińskiej, krajach katolickich, znalazł ludzi rozumiejących, czy to z przyczyn ideologicznych, czy religijnych, ten punkt widzenia.

\section{Recepcja Kapuścińskiego z perspektywy teoretycznej. Kilka uwag na zakończenie}

Poza wymienionymi wyznacznikami, czyli tradycją odkryć geograficznych (i związanym z nimi kolonializmem), ideologią oraz katolicyzmem, warto zwrócić uwagę na jeszcze jeden aspekt twórczości Kapuścińskiego, który poniekąd zazębia się $\mathrm{z}$ wymienionymi. Oto bowiem reporterowi udało się wpisać w teorię naukową rozwijającą się w latach osiemdziesiątych XX wieku, której celem była i jest głęboka dyskusja i analiza zagadnień podporządkowania wynikających z kolonializmu i imperializmu, a także zmiana dominującego porządku, mająca na celu pokazanie, jak wygląda świat z Bagdadu czy Benina, a jak z Berlina czy Bostonu ${ }^{64}$. Będąca dłużniczką marksizmu, poststrukturalizmu i humanizmu, nazywana jest teorią postkolonialną.

Mimo wszystkich podobieństw i różnic między wizją świata Kapuścińskiego a samym postkolonializmem warto zauważyć, że Kapuściński przekuł w praktykę wiele z założeń, na których teoria postkolonialna została zbudowana, i to już w swoich pierwszych książkach opublikowanych w latach sześćdziesiątych XX wieku.

${ }^{63}$ Por. Jan Paweł II, Sollicitudo rei socialis, 30.12.1987, http://www.vatican.va/content/john-paul-ii/pl/encyclicals/documents/hf_jp-ii_enc_30121987_sollicitudo-rei-socialis.html, dostęp: 19.05.2021.

${ }^{64}$ R.J.C. Young, Postkolonializm. Wprowadzenie, tłum. M. Król, Kraków 2012, s. 14. 
Moglibyśmy tym samym uznać go za prekursora zarówno pewnego sposobu myślenia zakorzenionego w praktyce humanistycznej, który pojawił się dwadzieścia lat później, jak i współczesnej teorii i krytyki literackiej uprawianej z tej perspektywy. A może raczej należałoby uznać, że w tym samym czasie, w którym pojawiły się te teorie, Kapuściński będący przede wszystkim praktykiem, świadkiem dekolonializmu, a dopiero później teoretykiem zderzył się z tymi samymi problemami, to jest jak pokazać świat z innej „równej” perspektywy, jak opisać Innych lub „podporządkowanych”, jak oddać im głos, jak wyjaśnić, co dzieje się w Afryce lub w Ameryce Łacińskiej, jak opisać życie ich mieszkańców.

\section{Bibliografia}

Alonso G., Gorgon J., Un periodista sin fronteras, „Reforma”, 28.01.2007.

Bąk G., Kapuściński, Ryszard [w:] Diccionario histórico de la traducción en España, Madryt 2009.

Cano A., El adiós de un cazador furtivo, „La Jornada”, 24.01.2007.

Carreño Carlón J., Las „fuentes” de Kapuściński y las de los medios mexicanos, „La Crónica”, 24.01.2007.

Domosławski A., Kapumania, kapumafia, „Gazeta Wyborcza”, 17.05.2005.

Domosławski A., Kapuścinski non-fiction, Warszawa 2010.

Druga Arka Noego, reż. P. Załuski, Telewizja Polska (Wrocław) 2000.

Espada A., Un tendal en Varsovia, „El Mundo”, 27.01.2007.

Herralde J., Por orden alfabético, Barcelona 2006.

Horodecka M., Zbieranie gtosów, Gdańsk 2010.

Jan Paweł II, Sollicitudo rei socialis, 30.12.1987, http://www.vatican.va/content/john-paul-ii/pl/encyclicals/documents/hf_jp-ii_enc_30121987_sollicitudo-rei-socialis.html, dostęp:19.05.2021.

Jauss H.R., Historia literatury jako wyzwanie rzucone nauce o literaturze (fragmenty), tłum. R. Handke, „Pamiętnik Literacki” LXIII, 1972, z. 4.

Kapuściński R. w rozmowie z A. Domosławskim, Wiosna ludów latynoskich, „Gazeta Wyborcza", 7.04.2001.

Kapuściński R. w rozmowie z W. Wiśniewskim, Być dla siebie surowym [w:] Autoportret reportera, red. K. Strączek, Kraków 2003.

Kapuściński R., Buszpo polsku, Warszawa 2008.

Kapuściński R., El cambio de función de la literatura después de la caída del totalitarismo, CCCB, Barcelona, 14.12.2002 (nagranie).

Kapuściński R., El Emperador, tłum. A. Orzeszek, R. Mansberger Amorós, Barcelona, 1989.

Kapuściński R., El encuentro con el Otro como reto del siglo XXI, Universitat Ramon Llull, Barcelona, 17.06.2005.

Kapuściński R., El Imperio, tłum. A. Orzeszek, Barcelona 1995.

Kapuściński R., El Sha o la desmesura del poder, tłum. A. Orzeszek, Barcelona 1982. 
Kapuściński R., Heban, Warszawa 1998.

Kapuściński R., La guerra del fútboly otros reportajes, tłum. A. Orzeszek, Barcelona 1992. Kapuściński R., Los cinco sentidos del periodista, México 2003.

Kapuściński R., Podróże z Herodotem, Kraków 2004.

Kapuściński R., Ten Inny, Kraków 2007.

Kapuściński R., Ttumacz-postać XXI wieku [w:] Podróże z Ryszardem Kapuścinskim, red. B. Dudko, Kraków 2007.

Kapuściński R., To nie jest zawód dla cyników, Warszawa 2013.

Kapuściński R., Wojna futbolowa, Warszawa 2010.

Mateos-Vega M., Murió Kapuściński, reconocido como el más grande reportero de la historia, „La Jornada”, 24.01.2007.

Milewski J.J., Gdyby cata Afryka... - dzisiaj. Postowie [w:] R. Kapuściński, Gdyby cata Afryka, Warszawa 2011.

Moix L., Kapuściński de cerca, „La Vanguardia”, 15.03.2007.

Nowacka B., „Ree-shard Kah-poosh-chin-skee”. Kapuściński po angielsku, „Pamiętnik Literacki” 2007, z. 3.

Orzeszek A., „Dreptania z(a) Kapuścinskim”[w:] Podróże z Ryszardem Kapuścińskim. Opowieści trzynastu ttumaczy, red. B. Dudko, Kraków 2007.

Roura V., Y critica, „El Financiero”, 24.01.2007.

Ryszard Kapuścinski: reportero del tercer mundo, red. R. Corredor Cure, Ó. Escamilla V., „Sala de Prensa”, listopad 2001, nr 27, http://www.saladeprensa.org/art287. htm, dostęp: 2.02.2014.

Taibo II P.I., Su influencia, fundamental para nosotros, „La Jornada”, 24.01.2007.

Turati M., Entraba por la puerta de la cocina, „Excelsior”, 24.01.2007.

Viñas D., Los géneros literarios [w:] Teoría de la literatura y literatura comparada, red. J. Llovet, Barcelona 2005.

Wiktorowska A., Rozmowa z A. Jornet, Barcelona, 4.03.2011.

Wiktorowska A., Ryszard Kapuścinski: visión integradora de un reportero. Clasificación, construcción y recepción de su obra [„Ryszard Kapuściński: integrujący obraz reportera. Klasyfikacja, budowa i recepcja jego twórczości”], Barcelona, Universitat de Barcelona, 2014, http://diposit.ub.edu/dspace/bitstream/2445/55125/1/Wiktorowska_Tesis.pdf, dostęp: 19.05.2021.

Wiktorowska A., Wywiad z J. Villoro, Meksyk, 19.02.2013.

Wiktorowska A., Wywiad z R. Herrscherem, Barcelona, 18.01.2013.

Wróbel A., Encyklika „Rerum novarum” - Magna charta katolickiej nauki spotecznej, „Studia Teologiczno-Historyczne Śląska Opolskiego” 2013, nr 33.

Young R.J.C., Postkolonializm. Wprowadzenie, tłum. M. Król, Kraków 2012. 